Vol. 9, No. 1, 2021, pp. 1-10

DOI: https://doi.org/10.29210/150100

Contents lists available at Jurnal IICET

Jurnal Konseling dan Pendidikan

ISSN: 2337-6740 (Print) ISSN: 2337-6880 (Electronic)

Journal homepage: http://jurnal.konselingindonesia.com

\title{
College students's social anxiety: a study of the young people mental health in the digital age
}

\author{
Cahyaning Suryaningrum ${ }^{*}$ \\ Universitas Muhammadiyah Malang, Indonesia
}

\begin{tabular}{l}
\hline Article Info \\
\hline Article history: \\
Received Nov $30^{\text {th }}, 2020$ \\
Revised Jan $04^{\text {th }}, 2021$ \\
Accepted Feb $03^{\text {rd }}, 2021$
\end{tabular}

Keyword:

College students

Gender

Social anxiety

\begin{abstract}
Purpose of this study is to analyze whether in the current era social anxiety problems are still developing among college students and whether there are any differences in the level of social anxiety was based on the year of entry (new college students - old college students) and gender. This research is a quantitative-descriptive and comparative studies. Hypotheses are there is no difference in social anxiety level based on the year of entry nor gender. The subjects are undergraduate college students totaled 364 people. Instrument used for data collection is Liebowitz Social Anxiety Scale-Self Report (LSAsSR). Results showed that $76.9 \%$ of the subjects experienced social anxiety. There is no difference in the level of social anxiety among new college students and old college college students nor between male college students and college students.
\end{abstract}

\section{Corresponding Author:}

Cahyaning Suryaningrum

Universitas Muhammadiyah Malang

Email: cahyaning@umm.ac.id

\section{Introduction}

In today's era, when the internet has become part of human life, it is undeniable that it also affects student life. Although on the one hand the internet (including social media) provides many conveniences, for example no longer having to meet or interact face-to-face, on the other hand it makes college students unfamiliar or trained to do real social interactions. Whereas social interaction significantly still needed because there are certain roles who remain need as well as the sensitivity and skills to train college students in social interaction. After all, the human side of humans still needs to be maintained even though life has entered the era of fast digital technology.

Someone who is not accustomed to or trained in social interaction can develop social anxiety. Social anxiety is a tendency to feel anxiety in social situations for fear of being judged negatively by others; get embarrassed or humiliated; and make others uncomfortable or dislike them ( American Psychiatric Association [APA], 2013; Antony \& Swinson, 2008; Henderson \& Zimbardo, 2010; McNeil, 2010). The social situation includes performance situation (when a person has to speak or perform in front of a crowd), and social interaction situation (when a person has to make social interactions with people he just knows) (APA, 2013).

Anxiety in social situations to some extent is said to be normal, adaptive and is a positive response. However, if it occurs frequently and excessively, it tends to be a problem and can develop into a more severe form; be a social anxiety disorder (Antony \& Swinson, 2008; APA, 2013; Butler, 2009).

Based on the cases during the counseling practices and observations, quite a lot of college students who complain of anxiety through a presentation in front of many people. Many also said that they were afraid when they had to express their opinions or ideas in academic discussions; facing an oral exam; even those that seem trivial, such as asking a lecturer during lectures or in a seminar. Generally they are afraid of being 
mistakes, afraid of being judged stupid, afraid of being laughed at and embarrassed; all of which are signs of a person experiencing social anxiety. However, social interaction in both performance situations and social interaction situations are needed required by college students related to its role in the context of the academic and social life.

This study aims to identify how far college students have developed social anxiety in the era of today. If the results of this study found that many college students experienced social anxiety, it need to get attention from professions associated with education and young people mental health. As the nation's successor, college students are expected to become "agents of change" that lead society to a better direction. Therefore, a good mental quality is needed, one of which is being "free" from the symptoms of social anxiety.

Another consideration that is used as the basis for the researcher's argument to state that social anxiety among college students is an important problem to research, that is by looking at the impact of social anxiety. Significant impacts include failure to continue college (dropping out of college) and graduation in taking exams (Topham \& Russel, 2012), poor academic perception and performance (Levpusceek \& Berce, 2011), academic adjustment and low self-adjustment in higher education ( Nordstrom, Goguen, Hiester, 2014). Diagnostic and Statistical Manual of Mental Disorders (5th ed.; DSM-5; APA, 2013) also mentioned that social anxiety disorder may increase the possibility of dropping out of school and quality of life.

By paying attention to the impact has been described above, in the end be very unfortunate if there are college students that has great potential to generate feat yet to be obstructed and fail because of its social anxiety. Social anxiety can "stop" a person from doing what he wants or is able to do; which in the long term if not treated can develop worse affecting social relationships, job success, education, and other activities (Antony \& Swinson, 2008; Butler, 2009). Nordstrom et al., (2014) said that social anxiety is a mental health condition that needs to be studied among college students because it has an impact on academic and social adjustment and is a very significant predictor of the low grade point average.

Although anxious in lecture situations is considered normal for college students (Topham \& Russel, 2012) and seems to be neglected (Vriends, Pfaltz, Novianti, \& Hadiyono, 2013), this is not the case according to researchers. By paying attention to the impact of youth, especially concerning the quality of the Indonesian nation is expected to become the nation's next ("agent of change"), the social anxiety among Indonesian college students is important to note. It is unfortunate if social anxiety is experienced by college students who have good potential and academic abilities but are unable to develop the abilities they actually have just because they experience social anxiety. Social anxiety among college students can be a reflection of the extent of mental health and the quality of youth as a nation's resource (Nordstrom et al., 2014).

There is an interesting finding, namely research from Vriends et al., (2013) which shows that Indonesian college students experience more social anxiety with a very significant difference compared to Swiss college students. The average level of social anxiety among Indonesian college students is 41.82; while Swiss college students were 30.15. A very significant difference also applies to the level of severe social anxiety with the percentage of Indonesian college students being 15.8\%; while Swiss college students were 6.2\%. The research subjects were 311 Indonesian college students from a university in Yogyakarta and 349 Swiss college students.

From several studies conducted in foreign countries, researchers saw that the level of social anxiety among college students in foreign countries was low. For example, research from Nordstrom et al., (2014) with 271 college students in America showed that 45\% of college students experienced low levels of social anxiety; $32 \%$ moderate level; and $23 \%$ of college students experienced a high level of social anxiety. Another study from Osso et al., (2014) which found out of 717 Italian college students, 61.4\% experienced low levels of social anxiety; $10 \%$ moderate level; and $28.6 \%$ classified as high level. Therefore, it is interesting to see the extent of social anxiety among Indonesian college students; whether much that is classified as high or low? Context Indonesian in this study not in the sense of territory geographic, but identity as Indonesian.

This research will also be extended by examining whether there are differences in the level of social anxiety between male college students and female college students. From epidemic and community studies, it is found that more women experience social anxiety (APA, 2013; Brook \& Schmidt, 2008; Hofmann, Asnaani, \& Hinton, 2010; Osso et al., 2014; Schreier et al., 2010). However, in clinical samples the number of men and women who experience social anxiety is relatively the same, even in some cases men show a larger number (APA, 2013).

On the other hand, Brook and Schmidt (2008) also said that some studies actually found no difference in social anxiety between men and women. Examples are research conducted by Moscovitch, Hofmann, and 
Litz (2005), Nordstrom et al., (2014); Schry, Norberg, Maddox, and White (2014) and DiBalsi, Cavani, Pavia, and Shimmenti (2015). The results of the study by Moscovitch et al., (2005) showed that sex differences did not affect the level of social anxiety. Because there are inconsistencies in the results of research related to gender and social anxiety, it is interesting to re-examine with a sample of Indonesian college students.

In addition, if in the literature it is stated that social anxiety can arise without having to have a previous history because of the new role it carries (APA, 2013; Nevid, Ratus \& Greene, 2007) then there is a possibility that new college students will have a higher level of social anxiety than old college students. However, according to the researchers' assumption, based on observations so far, there is no difference in the level of social anxiety between new college students and old college students.

Based on the background described above, the objectives of this study are to: 1) Identify the extent to which social anxiety problems develop among college students, 2) Test whether there are differences in the level of social anxiety between new college students and old college students with the hypothesis that there is no difference in social anxiety levels between new college students and old college students, 3) Test whether there is a difference in the level of social anxiety between male college students and female college students with the hypothesis that there is no difference in the level of social anxiety between male college students and female college students.

The benefits of this study are expected to contribute to matters related to the mental helath of young people, especially college students with the theme of social anxiety. If in the end it is found that the problem of social anxiety among Indonesian college students is still high, of course this needs to be a concern for professionals who are involved in the world of education and mental health of youth. Further research can be carried out finding factors that contribute to the development of social anxiety among the college students of Indonesia and try to explore is there cultural factors which lie behind them.

Furthermore, studies on intervention models to overcome college students social anxiety problem can be designed in harmony with the context of Indonesian culture or society. Thus, efforts to maintain and improve the Indonesian youth mental health especially college students can be more focused.

\section{Method}

This study is a quantitative-survey research that is descriptive and test for differences. The dependent variable of this study is social anxiety, while the status of college students based on the year of entry (new college students or old college students) and gender as independent variables.

The research subjects were undergraduate college students from two Universities in Malang totaled 364 people. Although continuing their studies in Malang, they came from various regions of Indonesia. There are 21 college students from Java Island; 15 from Sumatera Island; 71 people from Kalimantan; 41 from Sulawesi; 22 people from Nusa Tenggara Archipelago; and Madura Island as many as 4 people.

The number of male college students is 117 people while female college students are 247 people. There are 120 new batch students (entry year 2019); and old students (entry years 2017 and 2016) as many as 244 people. This is to find out whether the student is a new student or an old student and their gender by looking at the identity data listed by the student on the scale.

The data collection process is carried out in the classroom after taking certain courses with the permission of the course lecturers. At the time of data collection, the researcher first explains the aims and objectives of the research and the expected contribution of the subjects in this study. Researchers also inform the benefits and issues of confidentiality of subject identities . One form of maintaining the confidentiality of the subject's identity is that on the scale identity sheet the subject is not asked to include his name and only raises research results for the benefit of scientific publication. In addition, information regarding telephone numbers that can be contacted related to research (in this case the number of the researcher) is also conveyed. After understanding all this information, the subject is given the freedom to make decisions about his involvement in this research (in the form of willingness to fill out the scale). These steps were taken by researchers as an effort to fulfill research ethics.

The instrument used for data collection was the Liebowitz Social Anxiety Scale-Self Report (LSAS-SR) which had been translated into Indonesian. In this case the researcher is assisted by a teacher from the English Department in the translation. LSAS-SR is a social anxiety scale compiled by Michael Liebowitz in 1987; in its original version it is said to have very high validity. This scale contains 24 items designed to 
measure anxiety and avoidance in performance situations and social interaction situations. Research that has been done shows that this scale has superior internal consistency $(\alpha=0.90-0.96)$ and a test-retest reliability of 0.82 ( dos Santos, Loureiro, Crippa, \& Osorio, 2013). The results of the item discrimination power test and scale reliability that have been translated into Indonesian in this research show that the item discrimination power moves from 0.367 to 0.643 ; and the reliability of Cronbach's Alpha was 0.893 .

Based on the studies that have been carried out it is agreed by the researchers that the cut-off 30 is used to determine those who experience mild-moderate social anxiety, while the cut-off 60 is used to determine individuals who experience social anxiety at the level of severe social anxiety (Rytwinski et al., 2009). Thus, respondents who score less than 30 are categorized as not experiencing social anxiety. This norm is used by researchers to categorize college students into : 1) not experiencing social anxiety, 2) experiencing mildmoderate social anxiety, and 3) experiencing severe social anxiety.

Analysis of the data used is by using a percentage to present the results of the extent to which social anxiety exists among college students which includes the number of college students who experience social anxiety and its severity. To find out whether there is a difference in the level of social anxiety based on the year of admission (new students) and gender, a different test analysis technique ( $t$ test) was used which was processed using the SPSS-22 program.

\section{Results and Discussion}

The first objective of this research is to identify the extent to which social anxiety problems develop among college students. The results can be seen in Table 1 bellow:

Table 1. Description of the number and level of college students social anxiety

\begin{tabular}{lccccc}
\hline Category & $\begin{array}{c}\text { College students } \\
\text { (overall) (\%) }\end{array}$ & $\begin{array}{c}\text { New college } \\
\text { students (\%) }\end{array}$ & $\begin{array}{c}\text { Old college } \\
\text { students (\%) }\end{array}$ & $\begin{array}{c}\text { Male college } \\
\text { students (\%) }\end{array}$ & $\begin{array}{c}\text { Female } \\
\text { college } \\
\text { students (\%) }\end{array}$ \\
\hline Not experience & 23.1 & 25 & 22.1 & 25.6 & 21.9 \\
Mild-medium & 52.2 & 51.7 & 52.5 & 46.2 & 55.1 \\
Severe & 24.7 & 23.3 & 25.4 & 28.2 & 23.1 \\
Total \% & 100 & 100 & 100 & 100 & 100 \\
N & 364 & 120 & 244 & 117 & 247 \\
\hline
\end{tabular}

Table 1 shows that of the overall subjects more college students experienced social anxiety with a percentage of $76.9 \%$ (mild-moderate-severe) compared to those who did not. Based on the year of entry (new and old college students), there were also more college students who experienced social anxiety than those who did not. For new student subjects, it was $75 \%$, and old student subjects were $77.9 \%$. The largest percentage both for all subjects and based on the year of entry, are in the mild-moderate category with a percentage rate of $52.2 \%$ (overall subjects), $51.7 \%$ (new college students), and $52.5 \%$ (old college students).

When viewed by gender, both male and female college student also experienced social anxiety more than those who did not. The male subjects were $74.4 \%$, while the female subjects were $78.2 \%$. Similar to the level of social anxiety based on the year of entry, the largest percentage of social anxiety levels based on gender were also in the mild-moderate category. The male subject was $46.2 \%$, and the female student was $55.1 \%$.

The results above indicate that the problem of social anxiety among college students is high both when viewed based on the overall subject, year of entry and gender. Although the largest percentage is in the mildmoderate category, the percentage reaches more than $50 \%$ of the subjects as respondents.

Another result that deserves attention is the percentage value of subjects experiencing severe social anxiety. This number is not much different from those who do not experience social anxiety in all respondents, new and old college student groups, as well as male and female college students.

The second objective of this study is to test whether there is a difference in the level of anxiety between new college students and old college students. The homogeneity test showed that the two groups were homogeneous with a value of $F=0.289, p>0.05$. The results of the research to answer the second objective of this study can be seen in Table 2 .

Table 2 shows that there is no difference with the value of $t=-0.915, p>0.01$. This indicates that the problem of social anxiety is not only experienced by new college students but also experienced by old college 
students. Thus the hypothesis that there is no difference in the level of social anxiety between new college students and old college students is accepted.

Table 2. Differences in social anxiety levels by year of entry

\begin{tabular}{llcccc}
\hline \multicolumn{1}{c}{ Category } & $\mathbf{N}$ & Average & $\begin{array}{l}\text { Standard } \\
\text { deviation }\end{array}$ & $\mathbf{t}$ & $\begin{array}{c}\text { Significance } \\
\text { (p) }\end{array}$ \\
\hline $\begin{array}{l}\text { New college } \\
\text { students }\end{array}$ & 120 & 40,725 & 17,938 & $-0,915$ & 0.361 \\
$\begin{array}{l}\text { Old college } \\
\text { student } \\
\text { Total }\end{array}$ & 244 & 42,521 & 17,427 & & \\
\hline
\end{tabular}

These results can also imply that the problem of social anxiety among college students is not related to the year of entry as new college students or old college students. If we look at the average value of social anxiety levels, both groups are in the mild-moderate category. The mean score of the old college studenst subject group (42.521) was higher than the new college students subject group (40.725).

The third objective of this study was to determine whether there were differences in the level of social anxiety between male and female college students. The homogeneity test showed that the two groups were homogeneous with a value of $\mathrm{F}=0.357, \mathrm{p}>0.05$.

The results listed in Table 3 show that there is no difference in the level of social anxiety between male college students and female college students with a value of $t=-0.361, p>0.05$. Thus the hypothesis that there is no difference in the level of social anxiety between male college students and female college students is accepted. These results indicate that the high level of social anxiety experienced by college students is not significantly related to gender even though the mean value of the female student subject group (42.158) is higher than that of the male student subject group (41.444). Similar to the college students subject group based on the year of entry, the mean score of the male and female student subject groups indicated that the subject's anxiety level was in the mild-moderate category. Table 3 below is the result of research to answer the third objective.

Table 3. Differences in social anxiety levels based on gender

\begin{tabular}{llcccc}
\hline \multicolumn{1}{c}{ Category } & $\mathbf{N}$ & Average & $\begin{array}{c}\text { Standard } \\
\text { deviation }\end{array}$ & $\mathbf{t}$ & $\begin{array}{c}\text { Significanc } \\
\mathbf{e}(\mathbf{p})\end{array}$ \\
\hline Male & 117 & 41,444 & 17,891 & -0.361 & 0.718 \\
$\begin{array}{l}\text { Women } \\
\text { Total }\end{array}$ & 247 & 42,158 & 17,482 & & \\
\hline
\end{tabular}

The results of data analysis showed that there were more college students who experienced social anxiety than those who did not, both when viewed from all student subjects as well as by year of entry and gender. The percentage figure generally reaches more than $70 \%$ indicating that more than half of the research subjects experience social anxiety. This figure shows an increase when compared to the results of research from Suryaningrum (2006) and Suryaningrum in 2014 (Suryaningrum, 2016 ); research results from Vriends et al., (2013) and also research results from Hasibuan et al., (2015).

The study conducted by Suryaningrum (2006) showed that out of 211 college students, $43.12 \%$ experienced social anxiety. From the results of the next study in 2014 showed results that from 120 college students by $42.5 \%$ experienced social anxiety. The details are: $18.3 \%$ experienced mild social anxiety , $20 \%$ were in the moderate social anxiety category, and $4.17 \%$ experienced severe social anxiety (Suryaningrum, 2016). This data shows that almost half of all subjects experience social anxiety.

Another finding is the research of Hasibuan, Srisayekti, and Moeliono (2015). The subjects were 255 college students at a university in Bandung, using the Liebowitz Social Anxiety Scale (LSAS) as the instrument. The results showed that $20.9 \%$ of college students experienced mild social anxiety; 47.8 at moderate level; and $31.2 \%$ in the high category. This result is more increased than the findings of Suryaningrum from previous studies conducted in 2006 and 2014.

If the findings above are compared with the results of this study, it can be said that in the present era there are still quite a lot of college students who experience social anxiety and the percentage is relatively higher compared to the results of previous studies, namely from Suryaningrum (2006, 2016), Vriends et al., (2013) ) 
and from Hasibuan et al., (2015). The large number of college students who experience social anxiety will ultimately have an impact on the quality of the Indonesian youth. College students become unable to display the potentials and abilities they actually have because they are hampered by the social anxiety they experience. Thus the aspiration to produce quality young people who are able to become "agents of change" is hampered.

Based on this study, $24.7 \%$ of college students experienced severe social anxiety and $52.2 \%$ were in the mild-moderate category. Whatever the level of social anxiety is experienced by college students still need attention and should not be underestimated because of the extent of any social anxiety will still be an impact (Butler, 2009). If social anxiety is left unattended, it can develop into heavier and worse effects (Antony \& Swinson, 2008; Butler, 2009), become chronic (Cairney et al., 2007), and interfere with their life functions (APA, 2013). From a longitudinal study conducted by Vriends et al., (2006) for 1.5 years on 91 women who experienced social anxiety, it was found that $36.3 \%$ of the subjects still experienced social anxiety. This indicates that social anxiety can last even longer without treatment.

Although the results of this study are still limited to college students from two universities in Malang, but based on the research results of Hasibuan et al., (2015) with student subjects from Bandung, and Vriends et al., (2013) with student subjects from the city of Yogyakarta, shows an indication that quite a lot of Indonesian college students experience social anxiety. As a reference city to continue their studies, college students who continue their studies (college) in Yogyakarta, Bandung and Malang are likely not only native residents who come from Yogyakarta, Bandung and Malang. So, even though it does not include college students in all regions of Indonesia, these results at least provide an illustration of the problem of social anxiety among Indonesian college students. The real emphasis of the researcher is not on Indonesian college students in the context of geographic location or territory throughout Indonesia as stated in the introduction, but rather on identity as a person (student) who comes from Indonesia.

The high level of social anxiety among college students from year to year suggests the need to find the basic factors as causes and appropriate treatment models. The view that anxiety in academic situations (performance and social interactions) is normal appears to have contributed to this high rate of social anxiety.

The existence of new roles and demands as college students is seen as one of the factors that triggers many college students to experience social anxiety. College students are vulnerable to experience social anxiety compared to other communities because of the expectations and new roles assumed (Bella \& Omigbodun, 2009). Some college students reported that they started experiencing social anxiety after entering college. So, social anxiety can arise without having to have a previous history in childhood (Nevid et al., 2007) which generally arises because of exposure to stressful events or because of new roles in life (APA, 2013).

As is well known, academic life in higher education is full of performance and social interaction situations that must be endured. For example, in the lecture process they often have to appear/speak in front of many people, for example, presentations, express opinions in a discussion/forum, interact with new people to make friends or build relationships with authority figures and the community. There is a kind of demand that they must be able to face or do so as a consequence of being college students. This is even more so if these situations are related to assessments that will affect the Achievement Index, graduation and selfesteem. This is considered important by many college students because society and the academic community still use the Grade Point Average and fast graduation as a measure of success. In the end, this can cause social anxiety in themselves, especially coupled with a moral message not to embarrass themselves and their families (parents) which is a characteristic of collectivist society (Kitayama, 1991, 2010).

This anxiety may be felt more when college students become less accustomed to direct social interaction today because some sides have begun to be replaced by using social media or virtually. This in a way reduces opportunities to practice social skills, for example meeting new people or people in real social situations. In the end, when they have to interact in social situations they become anxious because they don't know, aren't sure what to do.

The above conditions can be explained through Self Presentation Theory regarding social anxiety from Schlenker and Leary which explains that a person will experience social anxiety if he is required to present himself as expected but hesitates to fulfill these expectations (Leary \& Jongman-Sereno, 2014). Related to this, the person's belief factor to be able to face/overcome the situation they face or known as self-efficacy (Bandura, 1977, 2009) also seems to have contributed. Research results have shown that self-efficacy plays a major role in reducing social anxiety (Fitzgerald, 2012; Iancu, Bodner, \& Ben-Zion, 2015; Moradi, Renani, 
Kajbaf, \& Neshat-Doost, 2012; Onyeizugbo, 2010; Rudy, Davis, \& Matthews, 2012; Sheperd, 2006; Tahmassian \& Moghadam, 2011; Tarkhan, Esmaeilpour, \& Tizdast, 2013; Treptow, 1999).

The results also showed that there was no difference in the level of social anxiety between new college students and old college students. The two groups of college students both showed mild-moderate levels of anxiety. The absence of this difference indicates that social anxiety can be experienced by college students regardless of the year of entry; whether new or old college students. So the assumption that new college students will experience more social anxiety because they are still in the adaptation period is not in line with the results of this study. If you pay attention to the average value of the social anxiety level of old college students, it is actually greater than that of new college students. In the category of severe social anxiety level, the subject group of old college students was even more experienced than new college students $(25.4 \%$ old college students; $23.3 \%$ new college students).

The greater the mean score of old college students compared to new college students in terms of social anxiety seems to be due to the increasingly diverse social situations that old college students have to face. The demand that as old college students be able to face various social situations is increasingly creating anxiety. In addition, they are getting closer to the final project preparation phase (thesis) and taking the thesis examination. For college students who experience social anxiety, meet with a supervisor for consultation; answer questions and express opinions during the consultation process; presenting his final assignment during the exam; answer examiner questions; is a scary situation.

In addition, as old college students they had received more input on negative experiences that they saw and heard from other people in various social situations. Through the learning process of vicarious (vicarious learning) that is learned through the experiences of others, college students can develop social anxiety more without having to experience it themselves (Bandelow, Charimo, Torrente, \& Ruther, 2005; Brook \& Schmidt, 2008; Essau \& Leung, 2008; Nevid et al., 2007 ).

Another possibility is the social anxiety they experienced when they were new college students or before did not get treatment or they did not seek treatment so that it became getting worse. Based on the results of research conducted by Suryaningrum (2006) and Vriends et al., (2013), college students who experience social anxiety actually requires therapy. It's just that they may feel reluctant and "embarrassed " when seeking help because it seems that in the academic community social anxiety is considered a common thing , it is worthless and must be faced (Topham \& Russel, 2012). In addition, the main characteristic of people who experience social anxiety is that they are afraid of getting negative judgments from others which makes them reluctant to go to professionals even though they need them.

Another result found from this study is that there is no difference in the level of social anxiety based on gender. If you only look at the overall average level of social anxiety, female college students are slightly higher but this difference is not significant.

As stated in the introduction or background section, studies aimed at examining differences in social anxiety between men and women have shown inconsistent results. The results of this study support studies that found no difference in social anxiety levels between men and women; and in accordance with the proposed hypothesis.

According to researchers, the absence of this difference is one possibility because the subjects studied were college students. Women who decide to pursue higher education or become college students are generally women who want to be more advanced. In the modern era, as now, that provide opportunities and equality between men and women, stimulates women to develop themselves one of them through education.

Among these female college students, there seems to be a shift that they also internalize the representation of masculine traits such as emphasizing self-esteem, independence, self-confidence, and assertiveness (Brook \& Schmidt, 2008) which are seen to reduce the risk of experiencing social anxiety (Hofmann et al., 2010). Female college students seem to realize that being a student will face many challenges; while there is no difference in treatment in the lecture process between men and women. Therefore female college students try to be able to overcome it and achieve the same as male college students.

Apart from the above results, there is an interesting thing to note that the male student group experienced more severe social anxiety than the female student group (see Table 1). Perhaps, in this group of male college students burdened with demands for masculine role stereotypes that emphasize competition, achievement (one of which is academic success) so that failure in this field is a shame (Oettingen, 2009). Meanwhile, in 
the discussion of gender and social anxiety, men are more unacceptable to show social anxiety than women (Rapee \& Spence, 2003).

The hope of the role that is emphasized by this society, for some men, it may be burdensome for themselves, thus causing them to experience social anxiety. This condition can also be explained through Self Presentation Theory as described above. Several studies have shown that in some countries the effects of social anxiety are greater for men than for women (Rapee \& Spence, 2003; Schry et al., 2014). In addition, it is also possible that male college students are more involved in the internet world or spend more time connecting with the internet. This can lead to less accustomed to direct social interaction. In the end, being less well trained and have the opportunity to air experience in social interaction which can give rise to social anxiety.

\section{Conclusion}

The conclusion of this study is that more college students experience social anxiety than those who do not. There is no level of difference in social anxiety between new college students and old college students or based on gender, indicating that these two factors are not a major factor in social anxiety.

The high number of cases of social anxiety among college students reflects the mental health conditions of Indonesian college students and the resources of Indonesia's youth that deserve attention. Therefore it is necessary for efforts to improve their psychological well-being and also designing interventions to improve the quality of youth resources. Suggestions for future researchers and practitioners in related fields are finding the fundamental factors that contribute to maintaining student social anxiety, especially the possibility of being related to cultural factors which can then be used as a basis for designing a treatment model that is in accordance with the characteristics of Indonesian college students.

\section{Acknowledgment}

Thank you to the University of Muhammadiyah Malang for its support in research funding.

\section{References}

American Psychiatric Association. (2013). Diagnostic and statistical manual of mental disorders (5th ed.). Washington, DC: Author.

Antony, M.M., \& Swinson, R.P. (2008). Shyness \& social anxiety workbook. Second edition. Canada: New Harbinger Publications, Inc.

Bandelow, B., Torrente, A.C., \& Ruter, E. (2005). The role of environmental factors in the etiology of social anxiety disorder. In B. Bandelow \& D.J. Stein (Eds.), Social Anxiety Disorder (pp. 117 - 126). New York: Marcel Dekker, Inc.

Bandura, A. (1977). Self-efficacy: toward a unifying theory of behavioral change. Psychological Review, 84 (2), 191-215.

Bandura, A. (2009). Exercise of personal and collective efficacy in changing societies. In A. Bandura (Ed.), Self-efficacy in changing societies (pp. 1-45). New York: Cambridge University Press.

Bella, T.T., \& Omigbodun, O.O. (2009). Social phobia in Nigerian University students: prevalence, correlates and co-morbidity. Social Psychiatry, 44 (6), 458-463.

Brook, C.A., \& Schmidt, L.A. (2008). Social anxiety disorder: A review of environmental risk factors. Neuropsychiatric Disease and Treatment, 4 (1), 123 - 143.

Butler, E. G. (1999). Overcoming social anxiety and shyness. London: Constable \& Robinson Ltd.

Cairney, J., McCabe, L., Veldhuizen, S., Corna, L.M., Streiner, D., \& Herrmann, N. (2007). Epidemiology of social phobia in later life. American Journal of Geriatric Psychiatry, 15, 224 - 233.

In Blasi, M., Cavani, P., Pavia, L., \& Shimmenti, A. (2015). The relationship between self-image and social anxiety in adolescence. Child and Adolescent Mental Health, 20 (2), 74 - 80.

Dos Santos, L.F., Loureiro, S.R., Crippa, J.A.de Souza., \& Osorio, F. de Lima. (2013). Psychometric validation study of Liebowitz Social Anxiety-Scale-Self-Reported version of Brazilian Portuguese. PLoS ONE, 8 (7). doi: 10.1317 / journal.pone.0070235

Essau, C.A., Leung, P.W., Conradt, J., Cheng, H., \& Wong, T. (2008). Anxiety symptoms in Chines and German adolescents: Their relationship with early learning experiences, perfectionism, and learning motivation. Depression and Anxiety, 25 (9), 801 - 810. 
Fitzgerald, N. (2012). The relationship between self-efficacy, social anxiety, personality types and strong anxious reactionism in a non-clinical sample of undergraduate students. Dublin Business School. Retrieved May 20, 2014, from DBS eSource.

Hasibuan, E.P.N., Srisayekti, W., \& Moeliono, M.F. (2015). The description of social anxiety is based on the Liebowitz Social Anxiety Scale (LSAS) in late adolescence in Bandung. Padjadjaran University Postgraduate Research Periodic Publication Journal, 1 - 10.

Henderson, L., Gilbert, P., \& Zimbardo, P. (2014). Shyness, social anxiety, and social anxiety disorder. In S.G. Hofman \& P.M. DiBartolo (Eds.), Social anxiety. Clinical, development, and social perspectives (3rd ed.) (Pp. 95 - 115). USA: Elsevier Inc.

Hofmann, S.G., Asnaani, A., \& Hinton, D.E. (2010). Cultural aspects in social anxiety and social anxiety disorder. Depression and Anxiety, 27 (12), 1117 - 1127.

Iancu, I., Bodner, E., Ben-Zion, I.Z. (2015). Self esteem, dependency, self-efficacy and self-criticism this social anxiety disorder. Comprehensive Psychiatry, 58, 165 - 171.

Leary, M.R., \& Jongman-Sereno, K.P. (2014). Social anxiety as an early warning system: a refinement and extension of the self-presentation theory of social anxiety. In S.G. Hofman \& P.M. DiBartolo, (Eds.), Social anxiety. Clinical, development, and social perspectives (3rd ed.) (Pp. 579 - 597). USA: Elsevier Inc.

Levpuscek, M.P. \& Berce, J. (2012). Social anxiety, social acceptance and academic self-perceptions in highschool students. Drus. Istraz. Zagreb God, 2 (116), 405 - 419.

Markus, H.R., \& Kitayama, S. (1991). Culture and the self: Implications for cognition, emotion, and motivation. Psychological Review, 98 (2), 224 - 253.

Markus, H.R., \& Kitayama, S. (2010). Culture and selves: A cycle of mutual constitution. Perspectives on Psychological Science, 5 (4), 420-430.

McNeil, D.W., \& Randall, C.L. (2014). Conceptualizing and describing social anxiety and its disorders. In S.G. Hofman \& P.M. DiBartolo, (Eds.), Social anxiety. Clinical, development, and social perspectives (3rd ed.) (Pp. 3-26). USA: Elsevier Inc.

Moradi, A., Renani, F.G., Kajbaf, M.B., \& Neshat-Doost, T.H. (2012). The effect of self-efficacy group training on the increase self-efficacy for social situations and decrease social phobia in female colleges of Isfahan University. International Journal of Advances in Psychology, (1), 10-17.

Moscovitch, D.A., Hofmann, S.G., \& Litz, B.T. (2005). The impact of self-construals on social anxiety: a gender-specific interaction. Personality and Individual Differences, 38, 659 - 672.

Nevid, J.S., Rathus, S.A., \& Greene, B. (2007). Psychology abnormal. Fifth edition. Volume 1. Jakarta: Erlangga.

Nordstrom, A.H., Goguen, L.M.S., \& Hiester, M. (2014). The effect of social anxiety and self-esteem on college adjustment, academics, and retention . Journal of College Counseling, (17), 48 - 63.

Onyeizugbo, E.U. (2010). Self-efficacy, gender and trait anxiety as moderator s of test anxiety. Electronic Journal of Research in Educational Psychology, 8 (1), 299 - 312.

Osso, L.D., Abelli, M., Pini, S., Carlini, M., Carpita, B., Macchi, E., ... Massimeti, G. (2014). Dimenional assessment of DSM-5 socialanxiety symptoms with functional impairment. Neuropsychiatric Disease and Treatment, 10, $1325-1332$.

Oettingen, G. (2009). Cross-cultural perspectives on self-efficacy. In A. Bandura (Ed.), Self-efficacy in changing societies (pp. 149-176). Cambridge University Press, digital printing, 2009.

Rapee, R.M., \& Spence, S.H. (2003). The etiology of social phobia: Empirical evidence and an initial model. Clinical Psychology Review, 24, 737 - 767.

Rudy, B.M., Davis, T.E., \& Matthews, R.A. (2012). The relationship among self-efficacy, negative selfreferent cognitions, and social anxiety in children: A multiple mediator model. Behavior Therapy, 43, 619 -628 .

Rytwinski, N.K., Fresco, D.M., Heimberg, R.G., Coles, M.E., Liebowitz, M.R., Cissell, S., ... Hofmann, S.G. (2009). Screening for social anxiety disorder with the self-report version of Liebowitz Social Anxiety Scale. Deppression and Anxiety, 26 (1), 34-38.

Schreier, S.-S., Heinrichs, N., Alden, L., Rapee, R.M., Hofmann, S.G., Chen, J., ... Bogels, S. (2010). Social anxiety and social norms in individualistic and collectivistic countries. Depression and Anxiety, 27 (12), 1128 - 1134.

Schry, A.R., Norberg, M.N., Maddox, B.B., \& White, S.W. (2014). Gender matters: the relationship between social anxiety and alcohol-related consequences. PloS ONE, 9 (12), 1-14. Doi: 10.1371 / journal.pone.0115361.

Sheperd, R-M. (2006). Volitional strategies and social anxiety among college students. College Quarterly, 9 (4), $1-10$. 
Suryaningrum, C. (2006). Indication of anxiety disorders in students of the Faculty of Psychology, University of Muhammadiyah Malang. Unpublished manuscript, Research Institute, Muhammadiyah University, Malang.

Suryaningrum, C. (2016). Student social anxiety: Preliminary study. Paper presented at the National Seminar on "Recent Research in Behavioral Science" on November 26, 2016, Gadjah Mada University, Yogyakarta.

Tahmassian, K., \& Moghadam, N.J. (2011). Relationship between self-efficacy and symptoms of anxiety, depression, worry and social avoidance in a normal sample of students. Iran Journal Psychiatry Behavior Sciences, $5(2), 91$ - 98.

Tarkhan, M., Esmaeilpour, M., \& Tizdast, T. (2013). A study of the relationship between social anxiety, social self-efficacy and body image in the girl students of the Islamic Azad University at Tonekabon Branch. Europian Online Journal of Natural and Social Sciences, 2 (4), 510 - 515.

Topham, P., \& Russel, G. (2012, April 4). Social anxiety in higher education. The Psychologist, 25,280 - 282.

Treptow, R.L. (1999). An examination of links between social anxiety and self-efficacy using adult's retrospective perceptions of socialization factors. Lincoln: University of Nebraska. (Papper AA19942161).

Vriends, N., Pfaltz, M.C., Novianti, P., \& Hadiyono, J. (2013). Taijin kyofusho and social anxiety and their clinical relevance in Indonesia and Switzerland. Frontiers in Psychology, 4 (3), 1-9. 